\title{
Lactational coumestrol exposure increases ovarian apoptosis in adult rats
}

\author{
Hyun-Ju Moon · Ji Hyun Seok · Soon Sun Kim • Gyu Seek Rhee • Rhee Da Lee • \\ Jun Young Yang $\cdot$ Soo Yeong Chae $\cdot$ Seung Hee Kim · Ji Young Kim • \\ Jin-Yong Chung $\cdot$ Jong-Min Kim $\cdot$ Soo Youn Chung
}

Received: 29 August 2008 / Accepted: 15 December 2008 / Published online: 23 January 2009

(C) The Author(s) 2009. This article is published with open access at Springerlink.com

\begin{abstract}
This study is the first to examine the increased apoptosis in the adult rat ovary after lactational exposure to coumestrol (COU), a potent phytoestrogen. Lactating dams were gavaged at doses of $0.01,0.1,1$, and $10 \mathrm{mg} / \mathrm{kg} \mathrm{COU}$ during the lactation period and the reproductive effects of female pups were investigated in young adults. Rats were sacrificed at postnatal days (PND) 81-84. Ovarian weights were reduced significantly at 0.1 and $1.0 \mathrm{mg} / \mathrm{kg}$ COU. The reduction in the ovarian weight occurred in parallel with an increase in the apoptosis at PND 135-140. A marked dosedependent increase in the expressions of active caspase-3 and -7 was observed in ovarian granulosa cells. Immunostaining for active caspase-3 and the TUNEL staining of apoptotic cells were also increased in ovaries exposed to COU in a dose-dependent manner. These results suggest new sights into the effect of lactational exposure to $\mathrm{COU}$ on the female reproductive health.
\end{abstract}

Keywords Ovarian apoptosis · Coumestrol · Lactational exposure $\cdot$ Caspase-3

This article has been approved for publication by KFDA, but the views presented in this article do not necessarily reflect those of the KFDA.

H.-J. Moon $(\bowtie) \cdot$ J. H. Seok · S. S. Kim · G. S. Rhee · R. D. Lee ·

J. Y. Yang $\cdot$ S. Y. Chae $\cdot$ S. H. Kim $\cdot$ S. Y. Chung

Reproductive and Developmental Toxicology Division,

National Institute of Toxicological Research,

Korea Food and Drug Administration,

194 Tongil-ro, Eunpyung-gu, Seoul 122-704, South Korea

e-mail: mhj1612@kfda.go.kr

J. Y. Kim · J.-Y. Chung $\cdot$ J.-M. Kim

College of Medicine, Dong-A University,

Busan 602-103, South Korea

\section{Introduction}

Coumestrol (COU) is a phytoestrogen isolated from a variety of clovers, alfalfa, and other leguminous plants which are food sources for both humans and farm animals. It has stronger binding activity to the estrogen receptor (ER) as compared with isoflavones (Adlercreutz and Mazur 1998). COU has been reported to have a higher affinity to $\operatorname{ER} \beta$ than to $\mathrm{ER} \alpha$ and its binding affinity to $\mathrm{ER} \beta$ is comparable or superior to that of estradiol (Kuiper et al. 1998). In contrast, COU acts as an anti-estrogenic compound by inhibiting the aromatase activity, and thus reduce the concentration of estrogens in the blood (Wang et al. 1994; Hong et al. 2008). The effects of phytoestrogens on mammalian health are very controversy and debated. Epidemiological data in Asians have demonstrated that higher soy consumption may result in a lower incidence of breast and prostate cancer (Adlercreutz et al. 1991; Kurzer and Xu 1997; Setchell and Cassidy 1999). Several studies in animals have shown that COU induced an increase in uterine weight, a decrease in ovulation rate, an increase in embryo degeneration, and the inhibition of ovarian cycles (Fredricks et al. 1981; McLachlan and Newbold 1987; Whitten et al. 1995; Tinwell et al. 2000).

Lactational period including the neonatal (postnatal days, PND, 1-10) and prepubertal (PND 11-21) stages is a particularly sensitive stage of rodent development as maturation of the reproductive organs takes place during this time. Several studies have been conducted to determine whether exposure to $\mathrm{COU}$ during periods of development exerts long-term effects on the reproductive system, even after the exposure has ended. Neonatally treated mice with $0.1 \mathrm{mg} /$ day COU for 5 days resulted in precocious vaginal opening, ovary-independent persistent vaginal cornification, absence of the corpora lutea, and ovarian hemorrhagic follicles (Burroughs et al. 1990a, b). Single neonatal injections 
of 1 and $3 \mathrm{mg} / \mathrm{kg}$ COU induced a reduction in ovarian weight of adult rats (Kouki et al. 2005). Lactationally exposed female rats induced a persistent estrus state at the dams consumed 2-4 mg of COU per day (Whitten et al. 1993, 1995). These results suggest that both direct and indirect neonatal exposures to $\mathrm{COU}$ result in permanent changes in the hypothalamo-hypophysial axis, as well as directly in the vagina and possibly in the ovary.

Since the developing infants could be exposed via mother's milk, lactation appears to provide a biologically significant route for study of COU-induced effects. Recent study demonstrated that COU was detected in soybean and mungbean sprouts but not soymilk or cow-milk based infant formula (Surh et al. 2006), suggesting that major food source of COU to infant can be breast milk or the bean sprout intake during the lactation period. In the present study, we intended to examine the COU-induced reproductive effects on female pups fed on milk, especially on the ovary with respect to apoptosis, which was not studied in vivo so far.

Estrogens are known to exert a protective effect against apoptosis in a variety of tissues and cells (Spyridopoulos et al. 1997; Evans et al. 1997; Garcia-Segura et al. 1998; Wang and Phang 1995; Tomkinson et al. 1997; Pelzer et al. 2000). In the ovary, estrogens increase follicular growth, ovarian weight, and the mitotic index of granulosa cells, and regulate granulosa cells apoptosis (Bendell and Dorrington 1991; Richards 1980). The antiapoptotic effects of estradiol-17 $\beta$ (E2) have been demonstrated via the observation of reduced caspase-3 activity (Tomkinson et al. 1997) and the modulation of the expression of genes such as bcl-2 (Schor et al. 1999).

Apoptosis is the form of cell death prevalent during follicular atresia and luteal regression (Boone et al. 1997; Dharmarajan et al. 1994), and is typically accompanied by the activation of caspases (Kumar 2007; Tilly 1996; Hsueh et al. 1994; Kaipia and Hsueh 1997). Caspase-3 is believed to be a key executioner in the apoptotic pathway (Porter and Janicke 1999) and its activation and expression induce apoptosis in several species of ovaries (Johnson and Bridgham, 2000; Van Nassauw et al. 1999; Boone and Tsang 1998; Matikainen et al. 2001) and cell types (Earnshaw et al. 1999). The presence of active (cleaved) caspase- 3 and -7 has been recognized as a reliable marker for the identification of apoptosis, and their combined function is required for the execution of cell death (Lakhani et al. 2006). Commonly applied methods to demonstrate apoptosis in mammalian ovary include TUNEL method and detection of caspase-3 (Otala et al. 2002; Carambula et al. 2002). The TUNEL method is highly specific and allows identification of apoptotic cells, and the method for detecting active caspase- 3 proves that the process of apoptosis in ovarian granulosa cells is completed. In this study, we examined COU-induced reproductive effects and the apoptotic activity in adult female rats using Western blotting, immunohistochemistry and TUNEL method.

\section{Materials and methods}

Animals and treatment

Pregnant Sprague-Dawley [Crl:CD (SD)] rats were obtained from the Laboratory Animal Resources, National Institute of Toxicological Research, Korea Food and Drug Administration (NITR/KFDA, Seoul, Korea) and maintained under controlled temperature $\left(22-24^{\circ} \mathrm{C}\right)$, humidity (50-60\%), and light (12 h light/12 h dark) conditions with food (Purina Korea, Seoul, Korea) and water available ad libitum. Pregnant dams were allowed to deliver their pups naturally. On PND 4, the litters were adjusted to contain eight pups by cross-fostering, with at least four females per litter, in order to allow for similar lactational exposure.

The dams were gavaged with $0.01,0.1,1$, and $10 \mathrm{mg} / \mathrm{kg}$ COU body weight per day from PND 1-21 at approximately the same time daily ( $n=6$ per group). The doses of COU (Biomol Research Laboratories, PA, USA) were based on prior studies by Whitten et al. (1993, 1995). Mean concentration, $10 \mathrm{mg} / \mathrm{kg}$, was determined as the highest dose of COU. On weaning day (PND 22), the female offspring were separated from the males and housed at four individuals per cage. After 84 days of age, the animals were rehoused in groups of three animals. The dams were terminated on PND 22 and female pups were sacrificed on PND 81-84 and PND 135-140. All of the animals were handled in an accredited KFDA animal facility in accordance with the guidelines for animal experiments of the Association for Assessment and Accreditation of Laboratory Animal Care (AAALAC) International Animal Care Policies (Accredited Unit-KFDA: Unit Number-000996).

\section{Clinical signs}

Throughout the study period, each animal, including the pups, was observed at least once daily for any signs of mortality, morbidity, injury, or toxicity. On working days, all cages were checked for dead or moribund animals in the morning and afternoon. The body weights of the pups were determined at necropsy.

\section{Necropsy}

Among the 24 female pups, ten were sacrificed by exsanguination from the abdominal vein under ether anesthesia on PND 81-84. The others were sacrificed within 2 months of PND 81 and their tissues were used in assessment of apoptosis by Western blot, TUNEL assay, and immunohis- 
tochemistry. The uterus and ovary were dissected and trimmed free of any adhering fascia and fat without any loss of luminal contents. The vagina was removed from the uterus at the level of the uterine cervix and then weighed. In addition, the liver, paired kidney, and adrenal weights were determined. The female rats were killed when the animal displayed a diestrus state within 4 days after PND 80 .

Tissue preparation and granulosa cell isolation

The rats were sacrificed by cervical dislocation and the ovaries were excised at PND 135-140. After the removal of connective tissues, the ovaries were washed briefly in PBS $(\mathrm{pH}$ 7.4) to remove excess blood and either immediately fixed in Bouin's solution for histological processing or used for granulosa cell isolation by follicle puncture with a needle.

\section{Western blot analysis}

Granulosa cells were separated from 6 to 8 rat ovaries per test. Freshly isolated granulosa cells were lysed in ice-cold PBS ( $\mathrm{pH}$ 7.4) containing $1 \%$ Nonidet P-40, $0.5 \%$ sodium deoxycholate, $0.1 \%$ SDS, and protease inhibitors $(1 \mathrm{mM}$ phenylmethylsulfonylfluoride, $10 \mathrm{mg} / \mathrm{ml}$ aprotinin, and $10 \mathrm{mg} / \mathrm{ml}$ leupeptin). The cell lysates were incubated on ice for $30 \mathrm{~min}$ and centrifuged $\left(13,000 \times g, 4^{\circ} \mathrm{C}, 30 \mathrm{~min}\right)$. The protein content of the supernatant was determined by a DC protein assay provided by Bio-Rad Laboratories, Inc. (Hercules, CA, USA). Equal amounts of proteins $(20 \mu \mathrm{g})$ in the cell extracts were resolved by SDS-PAGE (12\%) and electrotransferred to nitrocellulose membranes. The membranes were then blocked (room temperature, $1 \mathrm{~h}$ ) with Blotto [Tris-buffered saline, $\mathrm{pH} 8.0$, with $0.05 \%$ Tween-20 (TBS$\mathrm{T}$ ) and 5\% dried nonfat milk] and incubated (room temperature, $1 \mathrm{~h}$ ) with rabbit polyclonal anti-cleaved caspase-3 (Cell Signaling Tech; Beverly, MA, USA), rabbit polyclonal anti-cleaved caspase-7 (Cell Signaling Tech; Beverly, MA, USA) or mouse monoclonal anti-actin antibody (Sigma; St Louis, MO, USA). After the membranes were washed in TBS-T, secondary antibody reactions were conducted with an appropriate source of antibody conjugated with horseradish peroxidase. The signals were detected using an enhanced chemiluminescence detection kit (Amersham Pharmacia Biotech, Piscataway, NJ, USA) in a LAS3000 detector (Fujifilm, Japan), according to the manufacturer's instructions. The data was obtained from triplicates of each independent experiment.

In situ localization of apoptotic cells: TdT-mediated dUTP-biotin nick end labeling (TUNEL)

Paraffin sections were deparaffinized, hydrated, treated in $3 \% \mathrm{H}_{2} \mathrm{O}_{2}$ for $5 \mathrm{~min}$, then rinsed with PBS for $15 \mathrm{~min}$; then, the experiment proceeded in accordance with the instruction manual of the in situ Cell Death Detection Kit, POD (Roche, Penzberg, Germany). In brief, digoxigenin-dUTP end labeled DNA was detected with anti-digoxigenin-peroxidase antibody followed by peroxidase detection with diaminobenzidine (DAB). The tissues were then counterstained with 5\% methyl green. In the negative control slides, TdT enzyme was omitted in the labeling reaction. Apoptotic cell was determined by in situ TUNEL, and the number of TUNEL-positive follicle with apoptotic cells was counted in ovarian cross sections from four different rats under microscope at low magnification $(\sim 100 \times)$.

\section{Immunohistochemistry}

For caspase-3 immunohistochemistry, paraffin-embedded whole ovarian sections were incubated in $0.3 \% \mathrm{H}_{2} \mathrm{O}_{2}$ for $20 \mathrm{~min}$ and thoroughly rinsed with PBS for $15 \mathrm{~min}$. The sections were blocked with $1.5 \%$ normal goat serum in PBS (room temperature, $1 \mathrm{~h}$ ), then incubated with rabbit polyclonal anti-cleaved caspase-3 $(\sim 0.5 \mu \mathrm{g} / \mathrm{ml})$ in $1.5 \%$ normal goat serum (room temperature, $45 \mathrm{~min}$ ) in PBS. The sections were incubated at room temperature with biotin-conjugated secondary antibody $(1: 200,1 \mathrm{~h})$, avidin-biotinperoxidase complex (Vector Lab., Burlingame, CA, USA; $1 \mathrm{~h}$ ) and 3,3-diaminobenxidine tetrahydrochloride (DAB) solution $(1-5 \mathrm{~min})$. The nuclei were then counterstained with hematoxylin. For negative controls, rabbit IgG $(1 \mu \mathrm{g} /$ $\mathrm{ml}$ ) was added to the reaction instead of the primary antibodies.

\section{Statistics}

The data for the body and organ weights were statistically analyzed for any homogeneity of variance using Bartlett's test. One-way analysis of variance (ANOVA) was applied in cases in which the variance was homogeneous. In cases in which significant differences were detected, the difference between the control group and each group was analyzed by Dunnett's test. The criterion for significance was set at $P<0.05$. For semi-quantitative analysis, Duncan's test was used for comparison of mean values obtained with control versus COU groups, and either $P<0.05$ or $P<0.01$ was chosen to indicate a statistically significant difference.

\section{Results}

Clinical signs, body weights, and organ weights

No clinical signs or abnormalities were noted in any of the treatment groups. No significant differences in final body weight were observed between the vehicle control and the 
Table 1 Organ weights in adult female rats following exposure to coumestrol during the lactation period

\begin{tabular}{llllllll}
\hline $\begin{array}{l}\text { Treatment } \\
{[\mathrm{mg} /(\mathrm{kg} \text { per day) }]}\end{array}$ & $\begin{array}{l}\text { Final BW } \\
\text { (to 0.1 g) }\end{array}$ & $\begin{array}{l}\text { Uterus } \\
\text { (to 0.1 mg) }\end{array}$ & $\begin{array}{l}\text { Ovary } \\
\text { (to 0.1 mg) }\end{array}$ & $\begin{array}{l}\text { Vagina } \\
\text { (to 0.1 mg) }\end{array}$ & $\begin{array}{l}\text { Liver } \\
\text { (to 0.1 g) }\end{array}$ & $\begin{array}{l}\text { Adrenal } \\
\text { (to 0.1 mg) }\end{array}$ & $\begin{array}{l}\text { Kidney } \\
\text { (to 0.1 mg) }\end{array}$ \\
\hline Control & $267.8 \pm 12.4$ & $438.2 \pm 54.6$ & $92.7 \pm 16.2$ & $133.2 \pm 20.0$ & $9.3 \pm 0.8$ & $61.2 \pm 7.2$ & $1686.7 \pm 156.4$ \\
Coumerstrol 0.01 & $261.7 \pm 9.1$ & $392.4 \pm 72.9$ & $93.3 \pm 12.8$ & $119.3 \pm 19.6$ & $9.3 \pm 0.9$ & $56.5 \pm 8.1$ & $1612.5 \pm 118.4$ \\
Coumerstrol 0.1 & $262.5 \pm 8.3$ & $436.8 \pm 64.1$ & $80.1 \pm 8.5 *$ & $133.6 \pm 12.7$ & $9.5 \pm 0.7$ & $54.7 \pm 7.1$ & $1614.0 \pm 104.7$ \\
Coumerstrol 1.0 & $262.8 \pm 9.6$ & $405.6 \pm 66.3$ & $78.9 \pm 8.1 *$ & $130.7 \pm 30.2$ & $8.8 \pm 0.6$ & $65.9 \pm 13.2$ & $1588.3 \pm 126.7$ \\
Coumerstrol 10 & $261.8 \pm 8.2$ & $400.8 \pm 31.1$ & $82.4 \pm 6.4$ & $123.5 \pm 9.6$ & $8.9 \pm 0.4$ & $67.0 \pm 7.7$ & $1722.7 \pm 94.8$ \\
\hline
\end{tabular}

Values are means derived from ten animals \pm SD

* Significantly different from the control value $(P<0.05)$

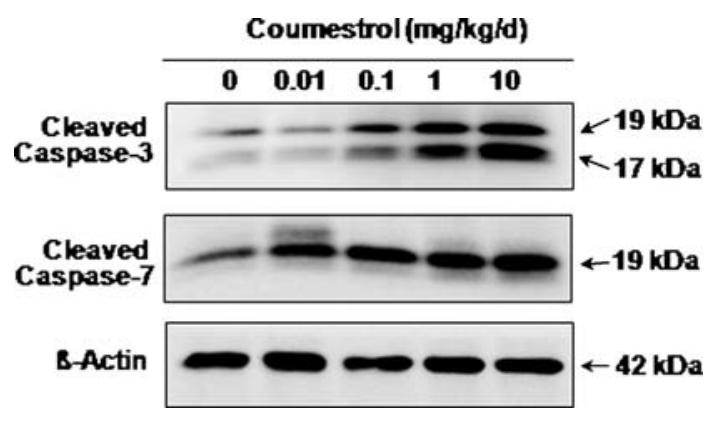

Fig. 1 Western blot for active caspase-3 and -7 during cell death (apoptosis) in ovaries of adult rats lactationally exposed to coumestrol $(0.01,0.1,1$, and $10 \mathrm{mg} / \mathrm{kg})$. Arrows indicate the positions of active caspase-3 (17 and $19 \mathrm{kDa})$ and $-7(19 \mathrm{kDa})$. These data are representative of results obtained from the analysis of three independent experiments (four rats per group)

COU group. The COU group showed a significant reduction in ovarian weight at 0.1 and $1.0 \mathrm{mg} /(\mathrm{kg}$ day). No significant differences in uterus, vagina, and other organ (liver, kidney, and adrenal gland) weights were observed (Table 1).

Expression of active caspase- 3 and -7 by Western analysis

The respective levels of the active caspase- 3 and -7 forms were determined by Western blotting using specific antibodies against the active forms. Two cleavage products of approximately 19 and $17-\mathrm{kDa}$ from the intact $32-\mathrm{kDa}$ of caspase-3 were observed in the protein extracts from granulosa cells. Similarly, the cleavage of caspase- 7 from the intact $35-\mathrm{kDa}$ protein to a $19-\mathrm{kDa}$ fragment was evident in the rat ovaries. The COU group displayed a marked dosedependent increase in the level of cleaved caspase- 3 and -7 (Fig. 1). This result was reproduced in three independent experiments conducted using four different rats per group.

Localization of the active (cleaved) caspase- 3 and apoptotic cell in ovarian section

To determine whether active caspase-3 was present and where to localize in the ovary, immunohistochemistry was performed using a rabbit polyclonal antiserum. The active caspase-3 staining was dose-dependently increased in granulosa cells of follicles of COU-exposed ovary compared to control (Fig. 2). It was also detected in the luteal tissues of control and COU-exposed ovaries. These results were obtained from the immunostaining in ovarian sections from four different rats.

In results of TUNEL staining, the apoptotic cells were detected in granulosa cells exposed to COU and visibly increased in the group of $10 \mathrm{mg} / \mathrm{kg}$ compared to control (Fig. 3a). In semi-quantitative analysis of TUNEL assay, the number of TUNEL-positive follicle with apoptotic granulosa cells was dose-dependently increased in ovarian sections from rats exposed to $\mathrm{COU}(P<0.05)$ (Fig. 3b).

\section{Discussion}

The phytoestrogens with respect to apoptosis have been focused on the inhibition of cell growth in various cancer cell lines or carcinogen-induced animal models. Genistein inhibited the growth of breast and ovarian cancer cells (Gercel-Taylor et al. 2004; Shim et al. 2007), and daidzein and biochanin-A directly induced apoptosis in bladder cancer cell (Su et al. 2000). So far, there was no information on the induction of apoptosis in estrogen target tissues by administration of phytoestrogens. The present study provided for the first time in vivo data for the phytoestrogeninduced apoptosis.

This study showed the increased apoptosis in the adult rat ovary after lactational exposure to COU. One previous study showed that the single neonatal injections of 1 and $3 \mathrm{mg} / \mathrm{kg}$ COU induced a reduction in ovarian weight of adult rats (Kouki et al. 2005) suggesting the ovarian toxicity. We are interested in the effect of COU on the ovary and assessed the apoptosis using Western blotting, immunohistochemistry, and TUNEL method. It was confirmed that COU significantly reduced the ovarian weight of adult female pups at concentrations of 0.1 and $1.0 \mathrm{mg} / \mathrm{kg}$ and dose-dependently increased the expression of caspases and the number of apoptotic cells in ovarian tissues. In addition, 
Fig. 2 Immunohistochemistry (IHC) of cleaved caspase-3 in ovaries of adult rats lactationally exposed to coumestrol $(0.1,1$, and $10 \mathrm{mg} / \mathrm{kg}$ ). Magnification, $\times 250$. OC oocyte, $G C$ granulosa cell, $T C$ theca cell, $L C$ luteal cell, $A T$ antrum. These data are representative of results obtained from the immunostaining in ovarian sections from four different rats
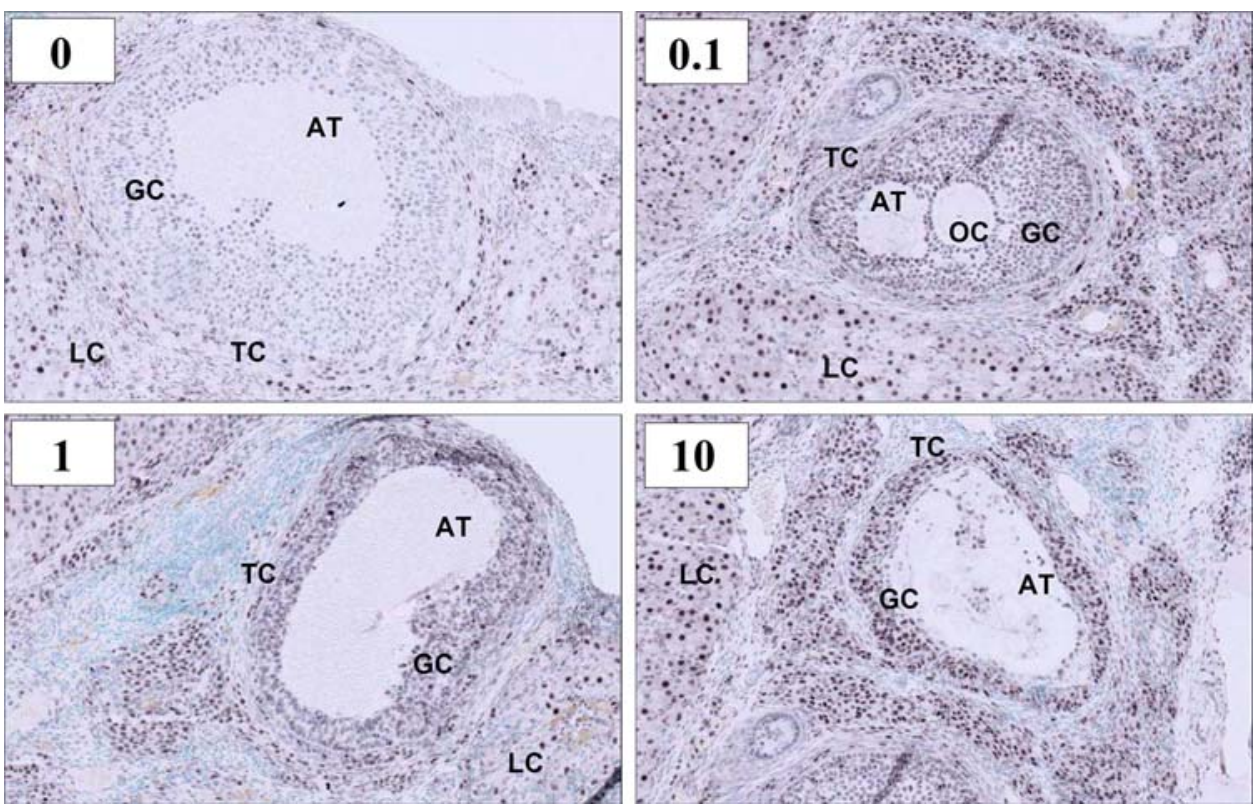

the female pups showed the regular cyclicity at PND 52-80 (data not shown). Whitten et al. (1993) observed that female offspring rats fed on a $0.01 \%$ COU ( $2-4 \mathrm{mg}$ /day) diet during the lactation exhibited regular cyclicity at 99-108 days but persistent vaginal cornification at 132-143 days. These results suggest that lactational COU-induced acyclicity may occur in the late period of adult rat.

The presence of apoptosis in atretic follicles was associated with decreased ovarian weight (Billig et al. 1993), decreased estrogen production, and declines in gonadotropin receptor mRNAs (Tilly et al. 1992). Estradiol benzoate dose-dependently prevented both DNA fragmentation and rat ovarian weight loss, while testosterone antagonized estrogen action by decreasing ovarian weight and increasing apoptosis in granulose cells of a subpopulation of preantral and early antral follicles (Billig et al. 1993). Estrogen also increased follicular expression of both FSH and LH receptors in rat granulose cells (Richards et al. 1976, 1979). Those follicles that do not produce significant amount of estrogen are more likely to possess less gonadotropin receptors. Our present data demonstrated that COUinduced decrease in ovarian weight was accompanied by increased apoptotic cell death. Even though no actual concentration of estrogen was given in this study, it is possible that COU-induced apoptosis causes decreases in ovarian weight and the expression of gonadotropin receptors, indicating androgenic effects of COU.

Caspase-3 is localized in both oocytes and granulosa cells of follicles undergoing atresia but not in granulosa cells of any small and single layered follicles (Fenwick and Hurst 2002). It was detected as a $32 \mathrm{kDa}$ band in Western blots of rodent ovary tissue extracts (Hu et al. 2001; Fenwick and Hurst 2002) and the cleaved fragments were found in apoptotic cells (Fuentes-Prior and Salvesen 2004; Degterev et al. 2003). Caspase-7 is very similar to caspase3 and exhibits a similar level of substrate specificity ( $\mathrm{Na}$ et al. 2007; Sung et al. 2007; Degterev et al. 2003). It is also activated in parallel with caspase-3 (Slee et al. 1999; Sun et al. 1999). In our Western results, the cleaved caspase- 3 was detected as proteins of 17 and $19 \mathrm{kDa}$ and cleaved caspase- 7 as $19 \mathrm{kDa}$ in granulose cell extract. This pattern of proteolysis was also observed in a study by Leblanc et al. 2003. The amounts of proteins of active caspase- 3 and -7 were elevated in a dose-dependent manner and in parallel with each other (Fig. 1), which was correlated with the increased granulosa cell apoptosis in immunohistochemistry and TUNEL assay (Figs. 2, 3).

In the immunostaining result, the active caspase- 3 was detected in granulosa and luteal cells but not the theca cells. Theca cell does not typically undergo apoptosis (Tilly 1996; Hsueh et al. 1994; Kaipia and Hsueh 1997; Palumbo and Yeh 1995). A recent study concerning the role of caspases in the activation of DNA degradation has suggested that in order for ovarian cells to complete the apoptotic program they must contain caspase-3, DNA fragmentation factor (DFF), and an endogenous nuclear DNase I (Liu et al. 1997). Activated caspase-3 targets DFF. Endogenous nuclear DNase I is contained in granulosa and luteal cells but not theca cells (Boone and Tsang 1997). Luteal cells require only a signal for the initiation of DNA degradation, whereas granulosa cells require both caspase-3 expression and a signal for this to occur (Boone and Tsang 1998). Our TUNEL assay results showed that the apoptosis occurs in the granulosa cell where the apoptotic cells were detected (Fig. 3).

Recent studies have shown that developmental exposure to genistein can cause alterations in the development of 
Fig. 3 a In situ detection of apoptotic cells (TUNEL) staining in ovaries of adult rats lactationally exposed to coumestrol $(0.1,1$, and $10 \mathrm{mg} / \mathrm{kg}$ ) during the lactation period. These photographs are representative of results obtained in ovarian sections from four different rats. Arrows point to the apoptotic cells. Magnification, $\times 250$. $O C$ oocyte, $G C$ granulosa cell, $T C$ theca cell, $L C$ luteal cell, $A T$ antrum. b Semi-quantitative evaluation of TUNEL assay. The number of TUNEL-positive follicles was counted in ovarian sections from four animals. Data are mean \pm SEM from 4 animals. $* P<0.05$ and $* * P<0.01$ by Duncan's test
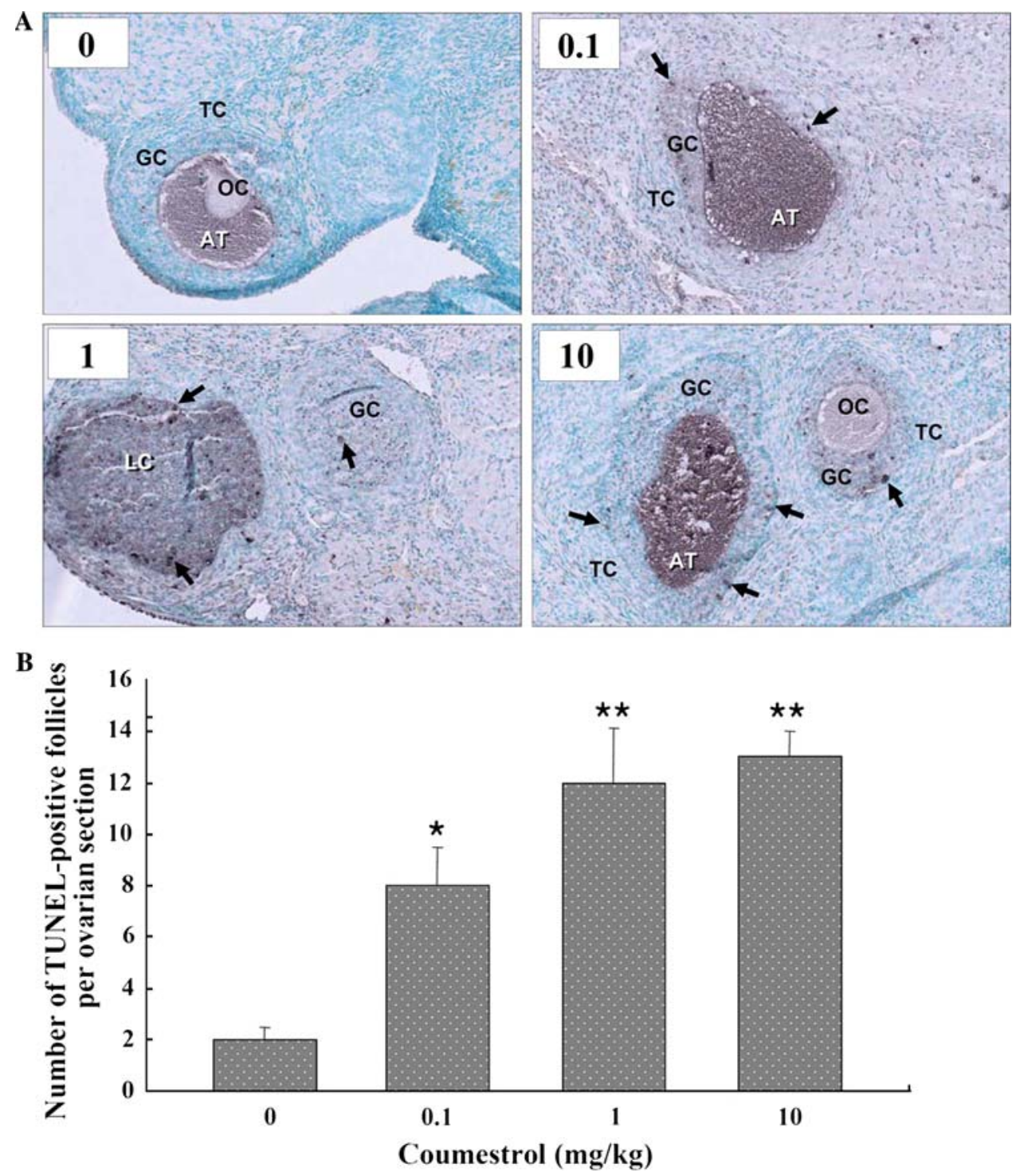

female reproductive tract of the rodent, including altered estrous cyclicity, altered ovarian function, subfertility, and infertility (Jefferson et al. 2005; Kouki et al. 2003; Levy et al. 1995; Nikaido et al. 2004). Our study suggests that the new insight into the effects of lactational exposure to COU together with genistein on the female reproductive health in adulthood. As much of the development occurring in the neonatal rat (during early lactation) is comparable to the latter two trimesters in human gestation (Pryor et al. 2000), the effects of the lactational exposure interval in this study imply that the possible effects of both in utero and lactational exposure of humans should be assessed. Also, with respect to the extension of our results to humans and other animals it will be important to investigate the role of individual differences in COU metabolism and response. This study suggests more detailed studies including the ovarian apoptosis-induced biological events in human and animal, underlying molecular mechanisms, and COUderived gene expression in adult.

Acknowledgment This study was supported by a grant (07141KFDA556) from Korea Food and Drug Administration in 2007.

Open Access This article is distributed under the terms of the Creative Commons Attribution Noncommercial License which permits any noncommercial use, distribution, and reproduction in any medium, provided the original author(s) and source are credited.

\section{References}

Adlercreutz H, Mazur W (1998) Overview of naturally occurring endocrine-active substances in the human diet. In: Dunaif GE, Olin SS, Scimeca JA, Thomas JA (eds) Human diet and endocrine modulation. ILSI Press, Washington, DC, pp 134-285

Adlercreutz H, Honjo H, Higashi A, Fotsis T, Hämäläinen E, Hasegawa T, Okada H (1991) Urinary excretion of lignans and 
isoflavonoids phytoestrogens in Japanese men and women consuming a traditional Japanese diet. Am J Clin Nutr 54:1093-1100

Bendell JJ, Dorrington J (1991) 17 $\beta$-Estradiol stimulates DNA synthesis in rat granulosa cells: action mediated by transforming growth factor-p. Endocrinology 128:2663-2665

Billig H, Furuta I, Hsueh AJ (1993) Estrogens inhibit and androgens enhance ovarian granulosa cell apoptosis. Endocrinology 133:2204-2212

Boone DL, Tsang BK (1997) Identification and localization of DNase I in the rat ovary. Biol Reprod 57:813-821

Boone DL, Tsang BK (1998) Caspase-3 in the rat ovary: localization and possible role in follicular atresia and luteal regression. Biol Reprod 58:1533-1539

Boone DL, Carnegie JA, Rippstein PU, Tsang BK (1997) Induction of apoptosis in equine chorionic gonadotropin (eCG)-primed rat ovaries by anti-eCG antibody. Biol Reprod 57:420-427

Burroughs CD, Mills KT, Bern HA (1990a) Long-term genital tract changes in female mice treated neonatally with coumestrol. Reprod Toxicol 4:127-135

Burroughs CD, Mills KT, Bern HA (1990b) Reproductive abnormalities in female mice exposed neonatally to various doses of coumestrol. J Toxicol Environ Health 30:105-122

Carambula SF, Matikainen T, Lynch MP, Flavell RA, Gonçalves PB, Tilly JL, Rueda BR (2002) Caspase-3 is a pivotal mediator of apoptosis during regression of the ovarian corpus luteum. Endocrinology 143(4):1495-1501

Degterev A, Boyce M, Yuan J (2003) A decade of caspases. Oncogene 22:8543-8567

Dharmarajan AM, Goodman SB, Tilly KI, Tilly JL (1994) Apoptosis during functional corpus luteum regression: evidence of a role for chorionic gonadotropin in promoting luteal cell survival. Endocr J 2:295-303

Earnshaw WC, Martins LM, Kaufmann SH (1999) Mammalian caspases: structure, activation, substrate, and functions during apoptosis. Annu Rev Biochem 68:383-424

Evans MJ, McLaughlin S, Marvin RD, Abdou NI (1997) Estrogen decreases in vitro apoptosis of peripheral blood mononuclear cells from women with normal menstrual cycles and decreases TNFproduction in SLE but not in normal cultures. Clin Immunol Immunopathol 82:258-262

Fenwick MA, Hurst PR (2002) Immunohistochemical localization of active caspase- 3 in the mouse ovary: growth and atresia of small follicles. Reproduction 124:659-665

Fredricks GR, Kincaid RL, Bondioli KR, Wright RW Jr (1981) Ovulation rates and embryo degeneracy in female mice fed the phytoestrogen coumestrol. Proc Soc Exp Biol Med 167(2):237-241

Fuentes-Prior P, Salvesen GS (2004) The protein structures that shape caspase activity, specificity, activation and inhibition. Biochem J 384:201-232

Garcia-Segura LM, Cardona-Gomez P, Naftolin F, Chowen JA (1998) Estradiol upregulates bcl-2 expression in adult brain neurons. NeuroReport 9:593-597

Gercel-Taylor C, Feitelson AK, Taylor DD (2004) Inhibitory effect of genistein and daidzein on ovarian cancer cell growth. Anticancer Res 24(2B): 795-800

Hong Y, Cho M, Yuan YC, Chen S (2008) Molecular basis for the interaction of four different classes of substrates and inhibitors with human aromatase. Biochem Pharmacol 75:1161-1169

Hsueh AJW, Billig H, Tsafriri A (1994) Ovarian follicular atresia: a hormonally controlled process. Endocr Rev 15:707-724

Hu X, Christian PJ, Thompson KE, Sipes IG, Hoyer PB (2001) Apoptosis induced in rats by 4-vinylcyclohexene diepoxide is associated with activation of the caspase cascades. Biol Reprod 65(1):87-93

Jefferson WN, Padilla-Banks E, Newbold RR (2005) Adverse effects on female development and reproduction in CD-1 mice following neonatal exposure to the phytoestrogen genistein at environmentally relevant doses. Biol Reprod 73:798-806

Johnson AL, Bridgham JT (2000) Caspase-3 and -6 expression and enzyme activity in hen granulosa cells. Biol Reprod 62:589-598

Kaipia A, Hsueh AJ (1997) Regulation of ovarian follicle atresia. Ann Rev Physiol 59:349-363

Kouki T, Kishitake M, Okamoto M, Oosuka I, Takebe M, Yamanouchi K (2003) Effects of neonatal treatment with phytoestrogens, genistein and daidzein, on sex difference in female rat brain function: estrous cycle and lordosis. Horm Behav 44:140-145

Kouki T, Okamoto M, Wada S, Kishitake M, Yamanouchi K (2005) Suppressive effect of neonatal treatment with a phytoestrogen, coumestrol, on lordosis and estrous cycle in female rats. Brain Res Bull 64:449-454

Kuiper GGJM, Lemmen JG, Carlsson BO, Corton JC, Safe SH, van der Saag PT, van der Burg B, Gustafsson J-A (1998) Interaction of estrogenic chemicals and phytoestrogens with estrogen receptor $\beta$. Endocrinology 139:4252-4263

Kumar S (2007) Caspase function in programmed cell death. Cell Death Differ 14:32-43

Kurzer MS, Xu X (1997) Dietary phytoestrogens. Annu. Rev Nutr 17:353-381

Lakhani SA, Masud A, Kuida K, Porter GA Jr, Booth CJ, Mehal WZ, Inayat I, Flavell RA (2006) Caspases 3 and 7: key mediators of mitochondrial events of apoptosis. Science 311:847-851

Leblanc V, Dery MC, Shooner C, Asselin E (2003) Opposite regulation of XIAP and Smac/DIABLO in the rat endometrium in response to 17beta-estradiol at estrus. Reprod Biol Endocrinol 1:59

Levy JR, Faber KA, Ayyash L, Hughes CL Jr (1995) The effect of prenatal exposure to the phytoestrogen genistein on sexual differentiation in rats. Proc Soc Exp Biol Med 208:60-66

Liu X, Zou H, Slaughter C, Wang X (1997) DFF a heterodimeric protein that functions downstream of caspase-3 to trigger DNA fragmentation during apoptosis. Cell 89:175-184

Matikainen T, Perez GI, Zheng TS, Kluzak TR, Rueda BR, Flavell RA, Tilly JL (2001) Caspase-3 gene knockout defines cell lineage specificity for programmed cell death signaling in the ovary. Endocrinology 142:2468-2480

McLachlan JA, Newbold RR (1987) Estrogens and development. Environ Health Perspect 75:25-27

Na KS, Park BC, Jang M, Cho S, do Lee H, Kang S, Lee CK, Bae KH, Park SG (2007) Protein disulfide isomerase is cleaved by caspase3 and -7 during apoptosis. Mol Cells 24:261-267

Nikaido Y, Yoshizawa K, Danbara N, Tsujita-Kyutoku M, Yuri T, Uehara N, Tsubura A (2004) Effects of maternal xenoestrogen exposure on development of the reproductive tract and mammary gland in female CD-1 mouse offspring. Reprod Toxicol 18:803811

Otala M, Erkkilä K, Tuuri T, Sjöberg J, Suomalainen L, Suikkari AM, Pentikäinen V, Dunkel L (2002) Cell death and its suppression in human ovarian tissue culture. Mol Hum Reprod 8(3):228-236

Palumbo A, Yeh JY (1995) Apoptosis as a basic mechanism in the ovarian cycle: follicular atresia and luteal regression. J Soc Gynecol Invest 2:565-573

Pelzer T, Schumann M, Neumann M, de Jager T, Stimple M, Serfling E, Neyses L (2000) 17 $\beta$-estradiol prevents programmed cell death in cardiac myocytes. Biochem Biophys Res Commun 268:192-200

Porter AG, Janicke RU (1999) Emerging roles of caspase-3 in apoptosis. Cell Death Differ 6:99-104

Pryor JL, Hughes C, Foster W, Hales BF, Robaire B (2000) Critical windows of exposure for children's health: the reproductive system in animals and humans. Environ Health Perspect 108:491-503

Richards JS (1980) Maturation of ovarian follicle: actions and interactions of pituitary and ovarian hormones on follicular differentiation. Physiol Rev 60:51-89 
Richards JS, Ireland JJ, Rao MC, Bernath GA, Midgley AR Jr, Reichert LE Jr (1976) Ovarian follicular development in the rat: hormone receptor regulation by estradiol, follicle stimulating hormone, and luteinizing hormone. Endocrinology 99:1562-1570

Richards JS, Jonassen JA, Rolfes AI, Kersey K, Reichert LE Jr (1979) Adenosine $3^{\prime}, 5^{\prime}$-monophosphate, luteinizing hormone receptor, and progesterone during granulosa cell differentiation: effects of estradiol and follicle stimulating hormone. Endocrinology 104:765-773

Schor NF, Tyurina YY, Tyurin VA, Kagan VE (1999) Differential membrane antioxidant effects of immediate and long-term estradiol treatment of MCF-7 breast cancer cells. Biochem Biophys Res Commun 260:410-415

Setchell KR, Cassidy A (1999) Dietary isoflavones: biological effects and relevance to human health. J Nutr 129:758S-767S

Shim HY, Park JH, Paik HD, Nah SY, Kim DS, Han YS (2007) Genistein-induced apoptosis of human breast cancer MCF-7 cells involves calpain-caspase and apoptosis signaling kinase 1-p38 mitogen-activated protein kinase activation cascades. Anticancer Drugs 18:649-657

Slee EA, Harte MT, Kluck RM, Wolf BB, Casiano CA, Newmeyer DD, Wang H-G, Reed JC, Nicholson DW, Alnemri ES, Green DR, Martin SJ (1999) Ordering the cytochrome c-initiated caspase cascade: hierarchical activation of caspases-2, -3, -6, -7, -8, and 10 in a caspase-9-dependent manner. J Cell Biol 144:281-292

Spyridopoulos I, Sullivan AB, Kearney M, Isner JM, Losordo DW (1997) Estrogen-receptor-mediated inhibition of human endothelial cell apoptosis. Estradiol as a survival factor. Circulation 95:1505-1514

Su SJ, Yeh TM, Lei HY, Chow NH (2000) The potential of soybean foods as a chemoprevention approach for human urinary tract cancer. Clin Cancer Res 6:230-236

Sun X-M, MacFarlane M, Zhuang J, Wolf BB, Green DR, Cohen GM (1999) Distinct caspase cascades are initiated in receptor-mediated and chemical induced apoptosis. J Biol Chem 274:5053-5060
Sung YH, Lee JS, Park SH, Koo J, Lee GM (2007) Influence of co-down-regulation of caspase-3 and caspase-7 by siRNAs on sodium butyrate-induced apoptotic cell death of Chinese hamster ovary cells producing thrombopoietin. Metab Eng 9:452-464

Surh J, Kim M, Koh E, Kim YK-L, Kwon H (2006) Estimated intakes of isoflavones and coumestrol in Korean population. Int J Food Sci Nut 57:325-344

Tilly JL (1996) Apoptosis and ovarian function. Rev Reprod 1:162172

Tilly JL, Kowalski KI, Schomberg DW, Hsueh AJ (1992) Apoptosis in atretic ovarian follicles is associated with selective decreases in messenger ribonucleic acid transcripts for gonadotropin receptors and cytochrome P450 aromatase. Endocrinology 131:1670-1676

Tinwell H, Soames AR, Foster JR, Ashby J (2000) Estradiol-type activity of coumestrol in mature, immature ovariectomized rat uterotrophic assays. Environ Health Perspect 108:631-634

Tomkinson A, Reeve J, Shaw RW, Noble BS (1997) The death of osteocytes via apoptosis accompanies estrogen withdraw in human bone. J Clin Endocrinol Metab 92:3128-3135

Van Nassauw L, Tao L, Harrisson F (1999) Distribution of apoptosisrelated proteins in the quail ovary during folliculogenesis: BCL2, BAX and CPP32. Acta Histochem 101:103-112

Wang TT, Phang JM (1995) Effects of estrogen on apoptotic pathways in human breast cancer cell line MCF-7. Cancer Res 55:24872489

Wang C, Makela T, Hase T, Adlercreutz H, Kurzer MS (1994) Lignans and flavonoids inhibit aromatase enzyme in human preadipocytes. J Steroid Biochem Mol Biol 50:205-212

Whitten PL, Lewis C, Naftolin F (1993) A phytoestrogen diet induces the premature anovulatory syndrome in lactationally exposed femalerats. Biol Reprod 49:1117-1121

Whitten PL, Lewis C, Russell E, Naftolin F (1995) Phytoestrogen influences on the development of behavior and gonadotropin function. Proc Soc Exp Biol Med 208:82-86 